\title{
THE CONCEPT OF THE TRACTOR POWERED BY BIODIESEL AND BIOGAS
}

\author{
Stanisław Wojciech Kruczyński, Grzegorz Pawlak \\ Warsaw University of Technology
Faculty of Automotive and Construction Machinery Technology \\ Narbutta Street 84, 02-524 Warsaw, Poland \\ tel.: +4822 2348782, fax: +48223426753 \\ e-mail: skruczyn@simr.pw.edu.pl,gpawlak@simr.pw.edu.pl
}

Ryszard Wołoszyn

\author{
Technical University of Radom \\ Mechanical Faculty, Institute of Maintenance of Vehicles and Machines \\ Chrobrego Street 45, 26-600 Radom, Poland \\ tel.: +48483617630 , fax: +48483617630 \\ e-mail:rw@pr.radom.pl
}

\begin{abstract}
Agriculture farms, especially animal farms consume a lot of energy. They also have big potential to produce energy by themselves. The production of biogas and its efficient utilisation could meet the need for fuel and energy. The production of biogas on a farm and its utilisation as a fuel could improve its energetic balance and safe some money. The paper describes the possible way of utilisation of upgraded manure biogas as a fuel for compression ignition engine, which is adopted for dual fuelling. The engine is going to be fuelled with vegetable oil ester and biogas produced directly on animal farm. Some calculation of fuel consumption of both fuels and analysis of possible changes of combustion process for dual fuelling mode are presented. There is also described the concept of adaptation of CI engine for agriculture tractor to dual fuelling with vegetable oil ester and biogas.

In Poland, there are about 1300 caw farms, 3000 pig farms and about 3500 chicken farms. Taking into account that the production of biogas is efficient and give some profit for minimum 100 caws, 500 pigs or 5000 chickens in the farm, there is together about 7800 farms where production of biogas could be profitable [2]. At the end of 2009 there were only 126 installation for biogas production and they produce $70.88 \mathrm{MW}$ of energy. Biogas is one of the most promising sources of renewable energy because the efficiency of conversion of biomass into fuel is relatively high
\end{abstract}

Keywords: biogas, dual fuel CI engine, agriculture tractor, sustainable energy

\section{Biogas as a fuel for sustainable energy production}

The renewable fuels create perspectives for practical realization of the idea of sustainable development, which includes clean and cheap energy production and its utilisation. Biomass is one of the potential renewable energy sources, which fits perfectly to the idea of balanced use of energy sources especially in the places where the renewable fuel could be produced and used. The share of biomass, which is used for energy production in the global balance, is rising but still there is a need to its increase (Fig. 1a). Perspective and still not fully exploited possibility is the utilization of biomass, which could be produced in agriculture farms. In Poland, there are about 1300 caw farms, 3000 pig farms and about 3500 chicken farms. Taking into account that the production of biogas is efficient and give some profit for minimum 100 caws, 500 pigs or 5000 chickens in the farm, there is together about 7800 farms where production of biogas could be profitable [2]. At the end of 2009, there were only 126 installations for biogas production and they produce $70.88 \mathrm{MW}$ of energy [3]. Biogas is one of the most promising sources of renewable 
energy because the efficiency of conversion of biomass into fuel is relatively high (Fig. 1b). Therefore, the research on this fuel application, which could broaden the usage of biogas, especially in the places where it is produced, is very important and perspective.
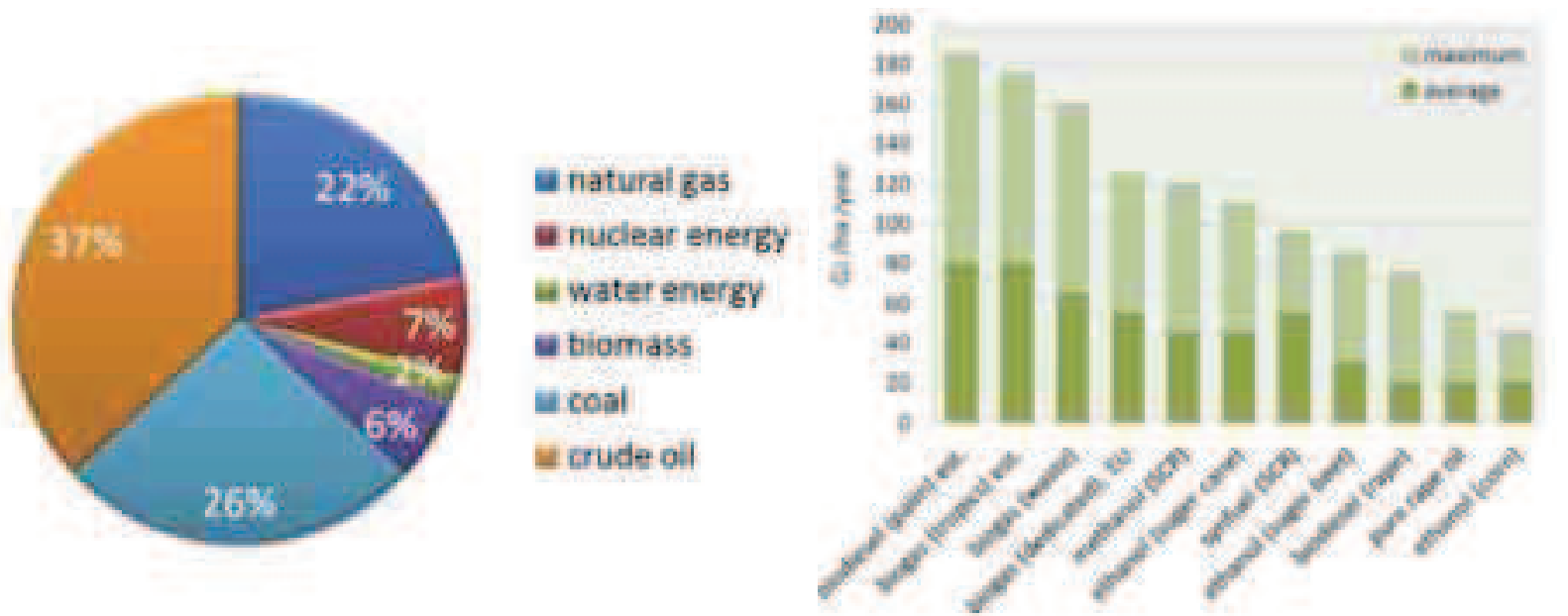

Fig. 1. a) The structure of word energy sources [1], b) Biofuels: net energy per hectare, convertible into liquid or gaseous fuels [4]

At present, manure biogas is used on-farm for direct electricity generation and some of the waste heat is recovered for other uses. There are other potential uses of biogas on a farm besides combined heat and power, such as in agricultural pumps, refrigeration, and vehicles.

The utilization of biogas as a fuel for agriculture vehicles is practically new area of research, which would allow for its wider application because for now there is neither an existing demand for raw biogas as a vehicle fuel.

\section{Biogas as a fuel for dual fuelling of $\mathrm{CI}$ engine}

From the point of view of application of biogas as a fuel, the most important factor is the component of methane in biogas. Methane is good, clean fuel for SI ignition engines because of its high octane number, high heating value and the content of carbon in the molecule, which is lower than in gasoline. Wide flammability range of methane allows creating a lean mixture and giving the possibility to get high engine thermal efficiency (Tab. 1). Application of this fuel to CI engines meets some barriers connected with low cetane number. Therefore, methane or natural gas (92-94\% of methane) is used as a fuel for dual fuel engines where the ignition process is realized by the pilot dose of diesel oil or vegetable oil ester which cetane number is high. The application of gaseous fuel for dual fuelling of CI engine demands an application of complicated fuel system but because of possible benefits in some cases, it is worth to pay the costs of it.

Tab. 1. Methane and biodiesel characteristic

\begin{tabular}{|l|c|c|}
\hline & Methane & Biodiesel \\
\hline Lower heating value $[\mathrm{MJ} / \mathrm{kg}]$ & 50 & $42.0-44.0$ \\
\hline Heating value of stoichiometric mixture $\left[\mathrm{MJ} / \mathrm{Nm}^{3}\right]$ & 3.37 & $3.745-3.922$ \\
\hline Stoichiometric air/fuel ratio $[\mathrm{kg} / \mathrm{kg}]$ & 17.2 & 14.5 \\
\hline Octane No. $[-]$ & 140 & - \\
\hline Cetane No. $[-]$ & - & $50-65$ \\
\hline Density $\left[\mathrm{kg} / \mathrm{m}^{3}\right]$ in $20 \mathrm{C}$ & 0.668 & $830-860$ \\
\hline Flammability limits [\% vol.] & $5-15$ & $0.6-6.5$ \\
\hline Autoignition temperature $[\mathrm{K}]$ & 923 & $603-623$ \\
\hline
\end{tabular}


Biogas consists of many components, which are formed during oxygen-free fermentation process, and the methane content depends on resources and conditions in which the biogas is created. Tab. 2 shows that the typical composition of raw (i.e., unprocessed) biogas does not meet the minimum $\mathrm{CNG}$ fuel specifications. In particular, the $\mathrm{CO}_{2}$, water vapour and sulphur (as contained in $\mathrm{H}_{2} \mathrm{~S}$ ) content in raw biogas is far too high for it to be used as a gaseous fuel for vehicles without additional processing.

Tab. 2. Compressed natural gas fuel specifications vs. typical raw biogas composition [5]

\begin{tabular}{|l|l|l|}
\hline \multicolumn{1}{|c|}{ Component } & \multicolumn{1}{|c|}{$\begin{array}{c}\text { CNG Fuel Specification } \\
\text { [\% vol.] }\end{array}$} & \multicolumn{1}{c|}{$\begin{array}{c}\text { Raw Biogas Composition } \\
\text { [\% vol.] }\end{array}$} \\
\hline Methane $\left(\mathrm{CH}_{4}\right)$ & $>88$ & $>48$ \\
\hline Ethane $\left(\mathrm{C}_{2} \mathrm{H}_{6}\right)$ & $<6$ & $<0.1$ \\
\hline $\mathrm{C}_{3}+($ Propane. etc. $)$ & $<3$ & $<0.1$ \\
\hline $\mathrm{C}_{6}+$ (Hexane. etc. $)$ & $<0.2$ & $<0.1$ \\
\hline Hydrogen $\left(\mathrm{H}_{2}\right)$ & $<0.1$ & $<0.1$ \\
\hline Carbon $\mathrm{Monoxide}(\mathrm{CO}))$ & $<0.1$ \\
\hline Oxygen $\left(\mathrm{O}_{2}\right)$ & $<0.1$ & $<0.1$ \\
\hline Inert gases & $<1$ & $<40$ \\
\hline Sulphur & $1.5-4.5$ & $50-2000 \mathrm{ppm}$ \\
\hline Dew Point & 16 ppm & Saturated \\
\hline Particulate matters & $<99 \%$ & Variable \\
\hline Odorant & Non-damaging to engines & Detectable \\
\hline
\end{tabular}

From the point of view of utilization of biogas to power a vehicle, it is very important to achieve possible high energy density of the gas fuel because of high weight of gas cylinder, which should be mounted on it. Biogas, which is purified, form $\mathrm{H}_{2} \mathrm{~S}$ and water is much cheaper than biomethane but includes less energy per mass unit. The lower heating value of biogas strongly depends on the content of $\mathrm{CO}_{2}$ in it (Fig. 2).

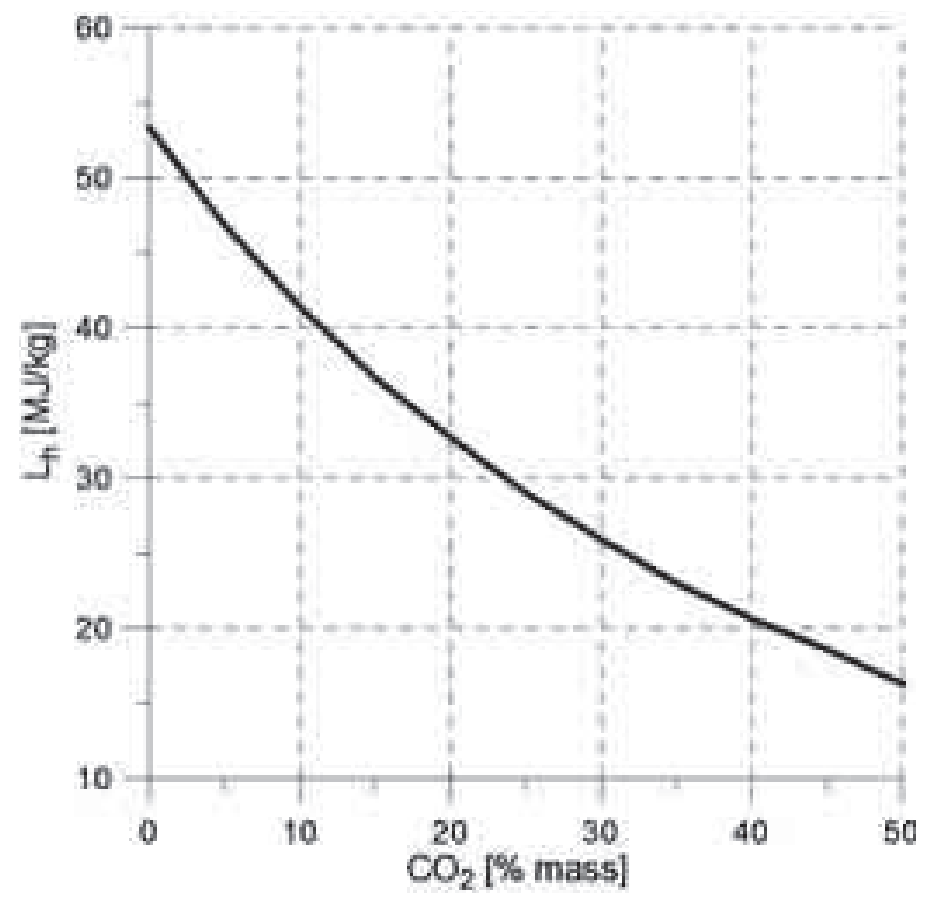

Fig. 2. The calculated lower heating value of biogas (3\% vol. $\mathrm{H}_{2}, 3 \%$ vol. $\left.\mathrm{O}_{2}\right)$ vs. mass content of $\mathrm{CO}_{2}$ in the biogas 


\section{The calculation of fuel consumption of biodiesel and biogas for dual fuelling of $\mathrm{CI}$ engine}

The goal of the planned research work is to increase a direct on-farm use of slightly cleaned biogas that has been upgraded through the removal of $\mathrm{H}_{2} \mathrm{~S}$, and water. Low energy density of biogas with high content of $\mathrm{CO}_{2}$ is one of the most important problems, which is a barrier for application of this fuel for a vehicle. In order to partially eliminate the problem it was decided to use biogas together with biodiesel. The mixture of biogas and biodiesel would be the fuel for CI engine powered agriculture tractor. For experiment, the agriculture tractor type Case IH MX135 was chosen and adapted for dual fuelling.

The planned adaptation demanded some calculation of vegetable oil ester and upgraded biogas consumption. The calculation should take into account the content of methane, which depends on the carbon dioxide content in biogas. For an example calculation the maximum torque from the engine speed characteristic was taken as a base (points $A_{P}$ and $A_{T}$ in Fig. 3). It was assumed that the engine demands the same amount of energy for fuelling with biodiesel only and for dual fuelling with biodiesel and biogas. It means that in case of dual fuelling of fully loaded engine the energy provided to the engine cylinder should be the same as the energy included in 24 litres of biodiesel (point $A_{F}$ in Fig. 3). It is also important that the tractor could be powered only with the use of vegetable oil ester in case of lack of biogas.

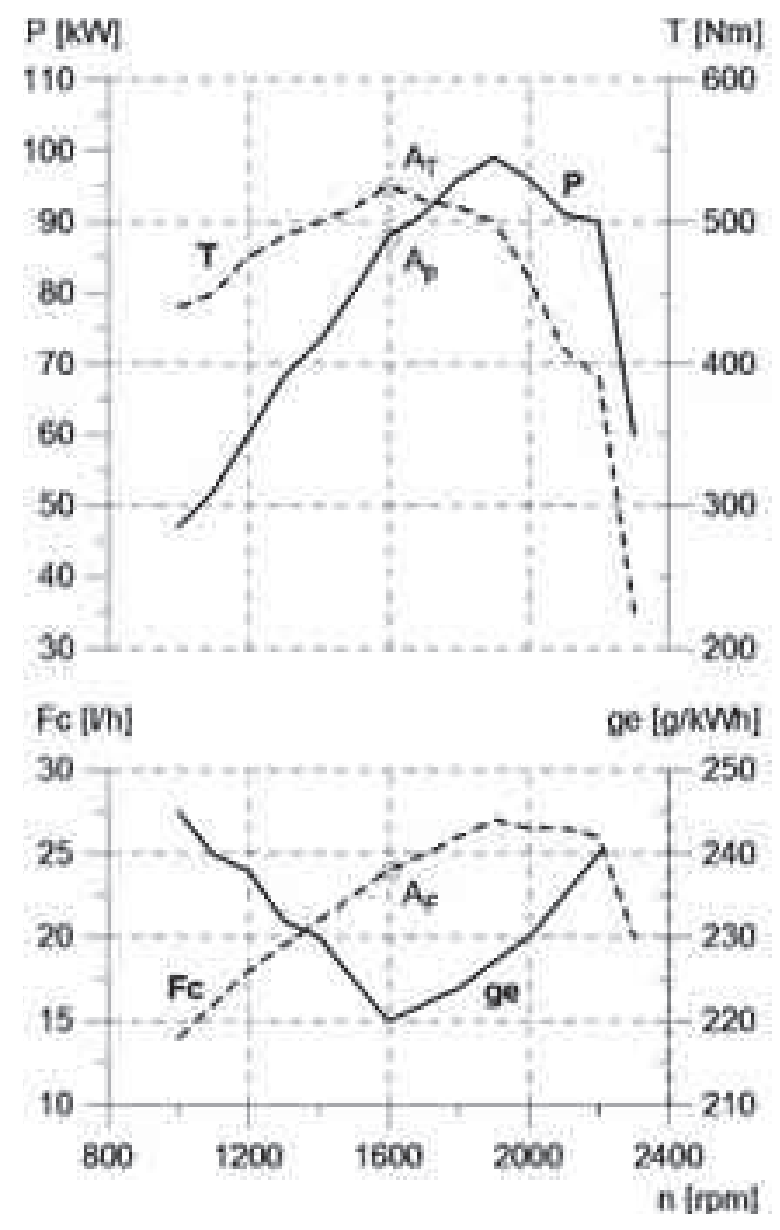

Fig. 3. The speed characteristic of CDC 6T-590 engine

The results of the simulation of consumption of biodiesel and biogas are presented in Fig. 4 . From the practical point of view, the biogas share in the dual fuel mixture should be confined to $20-30 \%$. For this share of biogas in the dual fuel mixture and for the typical manure biogas composition (58\% of methane in the biogas) the calculated biogas consumption exceeds 10-15 $\mathrm{kg} / \mathrm{h}$. It is sufficient for 4 hours run of fully loaded engine. 


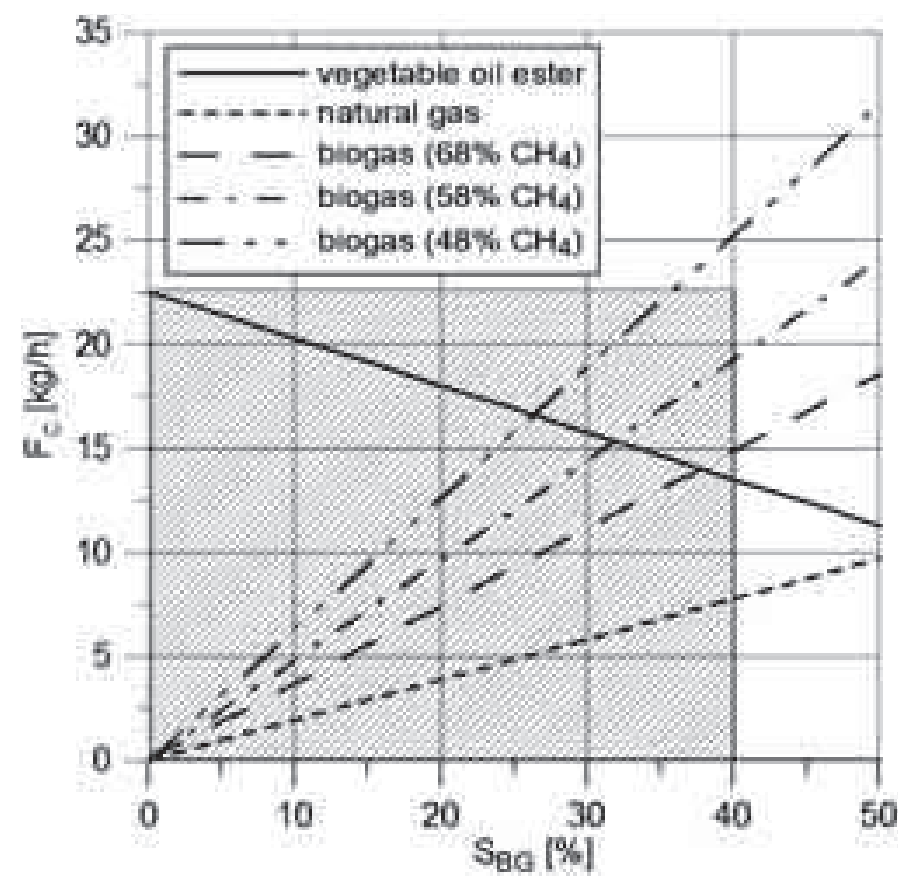

Fig. 4. Biodiesel and biogas consumption vs. the mass share of biogas in the dual fuel mixture /calculated/

In practice the tractor is $50 \%$ up to $70 \%$ loaded, so it is possible to use the dual fuel mode for about 8 hours a day. It enables to run the tractor for the working day and planned filling of biogas during the night. The calculated biogas consumption demands application of five gas cylinders. The volume of each cylinder should be 40 litres (10 kg of biogas capacity). The biogas would be stored under the pressure about 16-20 MPa.

\section{Combustion of biogas and biodiesel in CI engine}

The dual fuelling of CI engine with biogas and vegetable oil ester could change of volumetric efficiency of the engine. As a consequence of the drop of volumetric efficiency and because of the mechanism of dual fuel mixture ignition and flame propagation the modification of processes, which take place in the engine cylinder, is expected. The high volume of biogas provided to the inlet pipe and compressed together with the air without extra regulation of turbocharger bypass may contribute to the drop of air excess ratio $\lambda$ The phenomenon of the change of $\lambda$ for different mass share of biogas in the mixture and for the different biogas, composition was also analyzed. The results of calculation of $\lambda$ is presented in Fig. 5 .

The content of biogas in the dual fuel mixture which is higher than $30 \%$ causes the drop of $\lambda$ which could affect the combustion process, especially cause the increase of hydrocarbon and carbon monoxide emission. The combustion process of dual fuel mixture in CI engine is very complex. It is initiated by the self-ignition of the dose of biodiesel and the flame spreads in the combustion chamber, which is filled with homogeneous biogas-air mixture.

In order to analyze some phenomena of dual fuel combustion the model of dual-fuel engine cycle was prepared. It was created with the use of AVL BOOST software [6]. In the simulation, the same amount of heat is provided to one cycle but the heat is generated from biodiesel only or from the combustion of the mixture of biodiesel and biogas. It was assumed that the higher mass share of biogas, which is diluted with carbon dioxide in dual fuel mixture the longer period of combustion, could be expected and the period of combustion is proportional to the share of biogas in the mixture. The combustion process was simulated with the use of double Vibe function [7]. The results of the simulation consisted of the curves of rate of heat release (Fig. 6) cylinder temperature (Fig. 7) and pressure (Fig. 8) as well as indicated mean effective pressure (Fig. 9). 


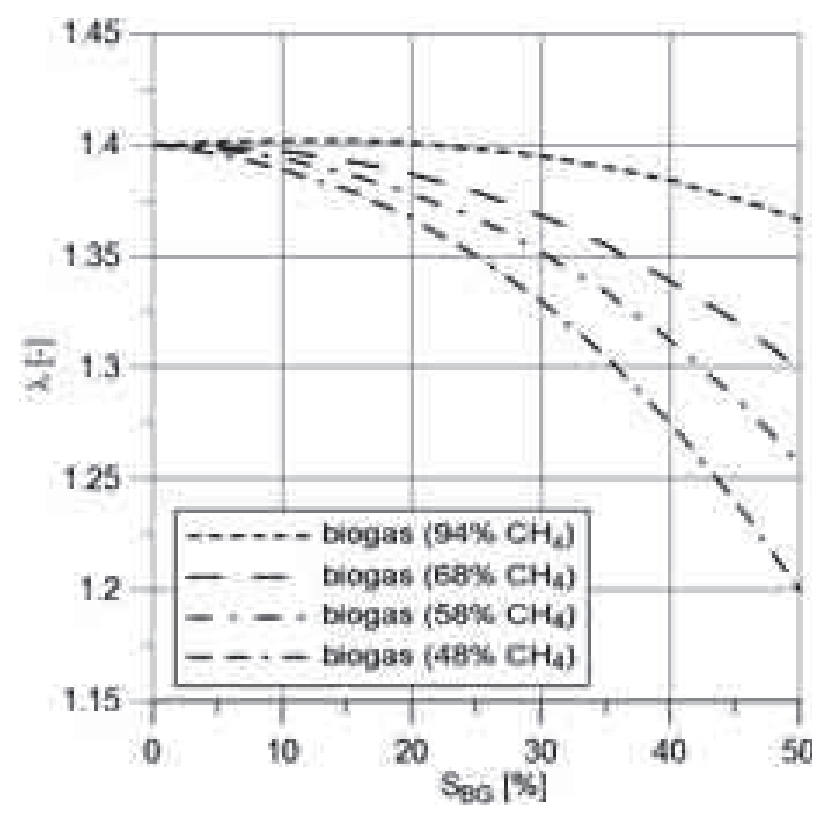

Fig. 5. The air excess $\lambda$ ratio vs. share of biogas in the dual fuel mixture for different content of methane in biogas /calculated/

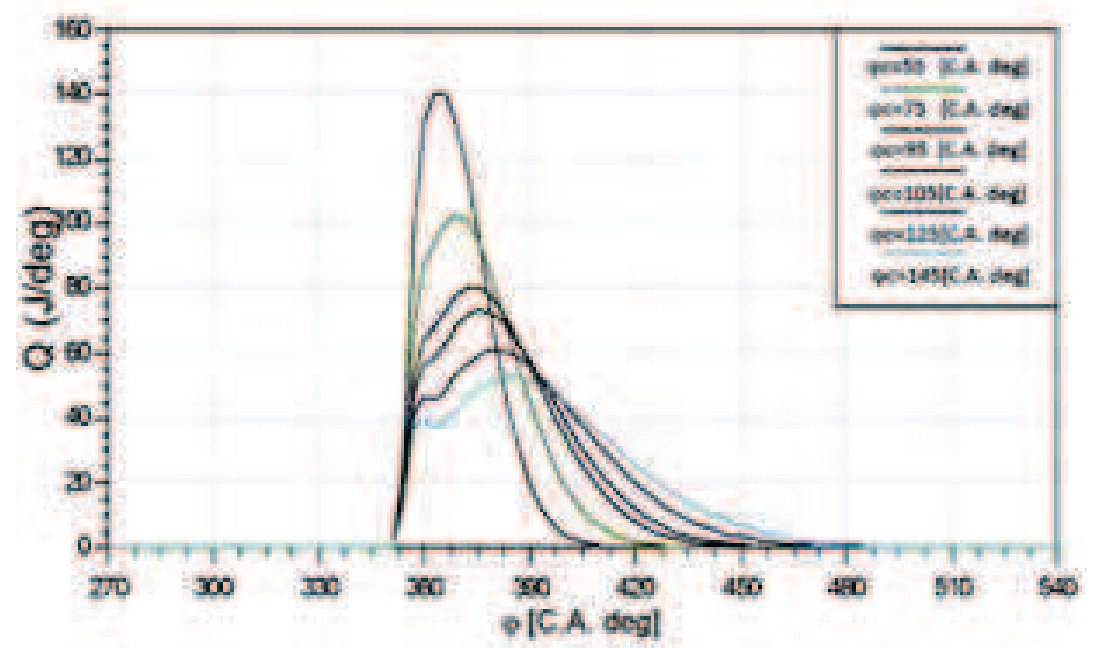

Fig. 6. The rate of heat release calculated for six values of combustion period $(\varphi c)$

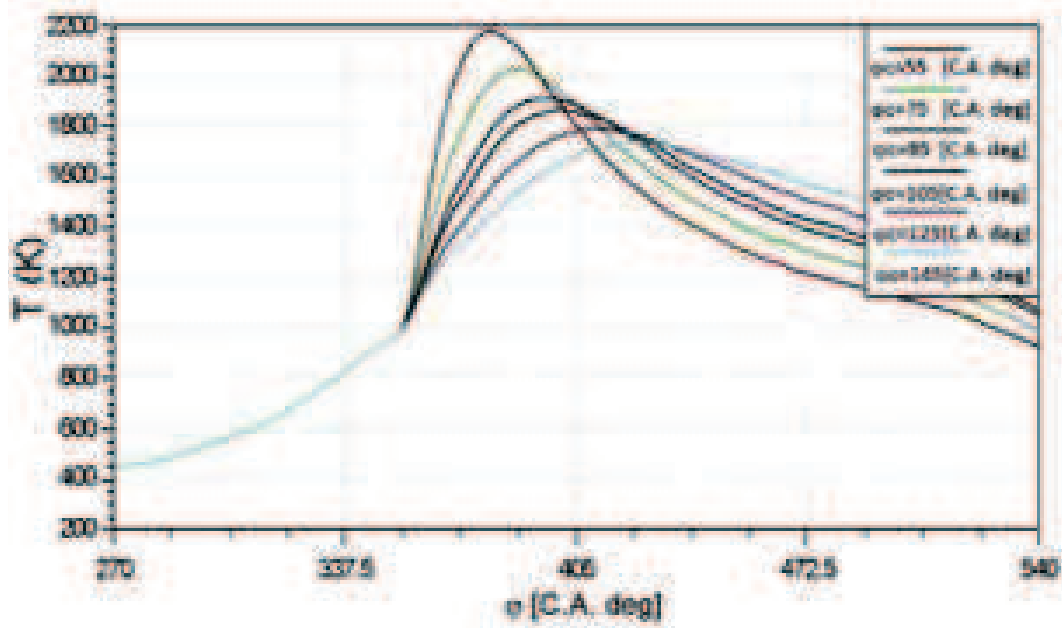

Fig. 7. The cylinder temperature calculated for six values of combustion period $(\varphi c)$ 


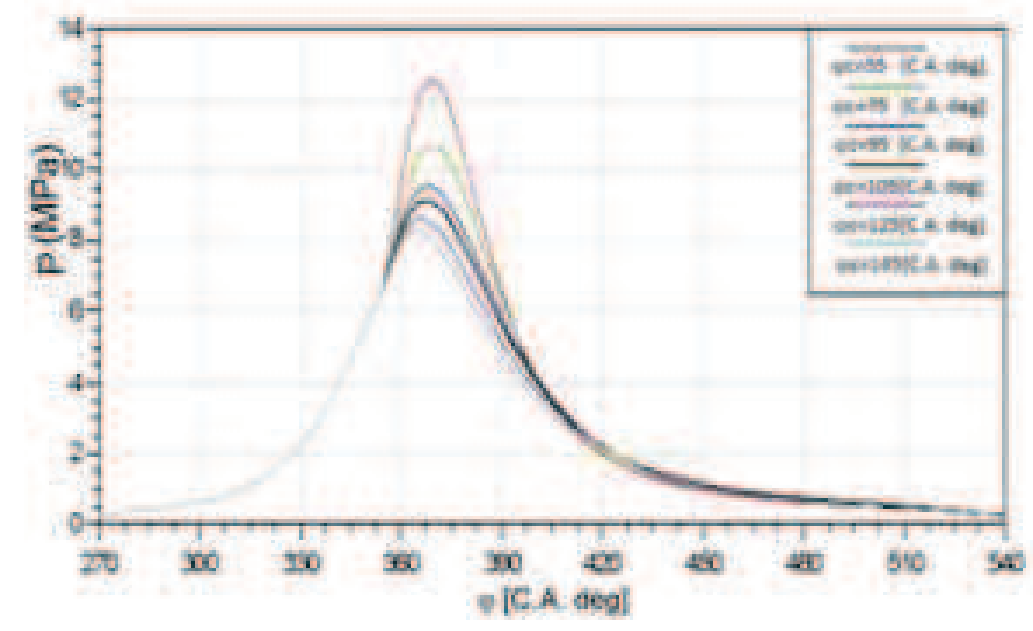

Fig. 8. The cylinder pressure calculated for six values of combustion period $(\varphi c)$

The temperature and pressure diagrams show that there is a limit of possible length of the combustion process. When the process takes more than 100 deg C.A., the temperature of exhaust gases is too high and the indicated mean effective pressure drops because of low maximum value of cylinder pressure (Fig. 9). The simulation confirmed that there is a limit of biogas share in the mixture as well as there is a limit of the content of carbon dioxide in biogas. The minimum mass share of methane in the biogas should be higher than 58-60\%.

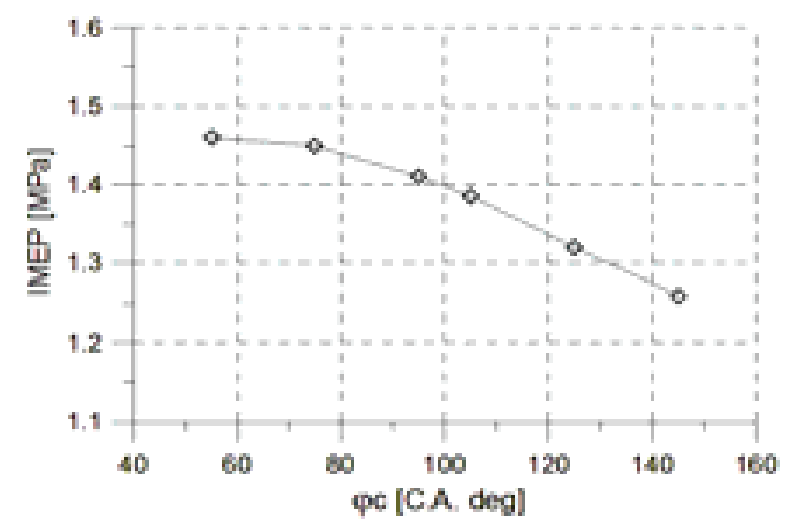

Fig. 9. Calculated indicated mean effective pressure vs. combustion period ( $\varphi c)$

\section{The adaptation of Case IH MX135 tractor for dual fuelling with biodiesel and biogas}

As a result of analysis of biogas consumption and combustion of dual fuel mixture, the concept of dual fuelling of the agriculture tractor was elaborated. The standard turbocharged engine type CDC 6T-590 is equipped with injection pump. Additionally the tractor is too equipped with gas installation. In order to confine the biodiesel dose which must be replaced by biogas there is elaborated a special mechanism, which reduce the dose of the injected biodiesel according to the planned strategy of fuelling of the engine. The strategy is similar to that which is described in [8]. The scheme of biogas installation is shown in Fig. 10.

Before the conversion of the engine to dual fuelling with biodiesel and biogas the maximum engine power is $99 \mathrm{~kW}$ for $1900 \mathrm{rpm}$ and the maximum engine torque exceeds $525 \mathrm{Nm}$ for 1800 rpm. It is expected that after conversion the engine performance would change but the possible drop of maximum torque should not affect the tractor abilities and functionality. The higher mass share of biogas is planned to be applied for part load of the engine but for the full load, the engine is fuelled only with biodiesel or with the mass share of biogas lower than $10 \%$. 


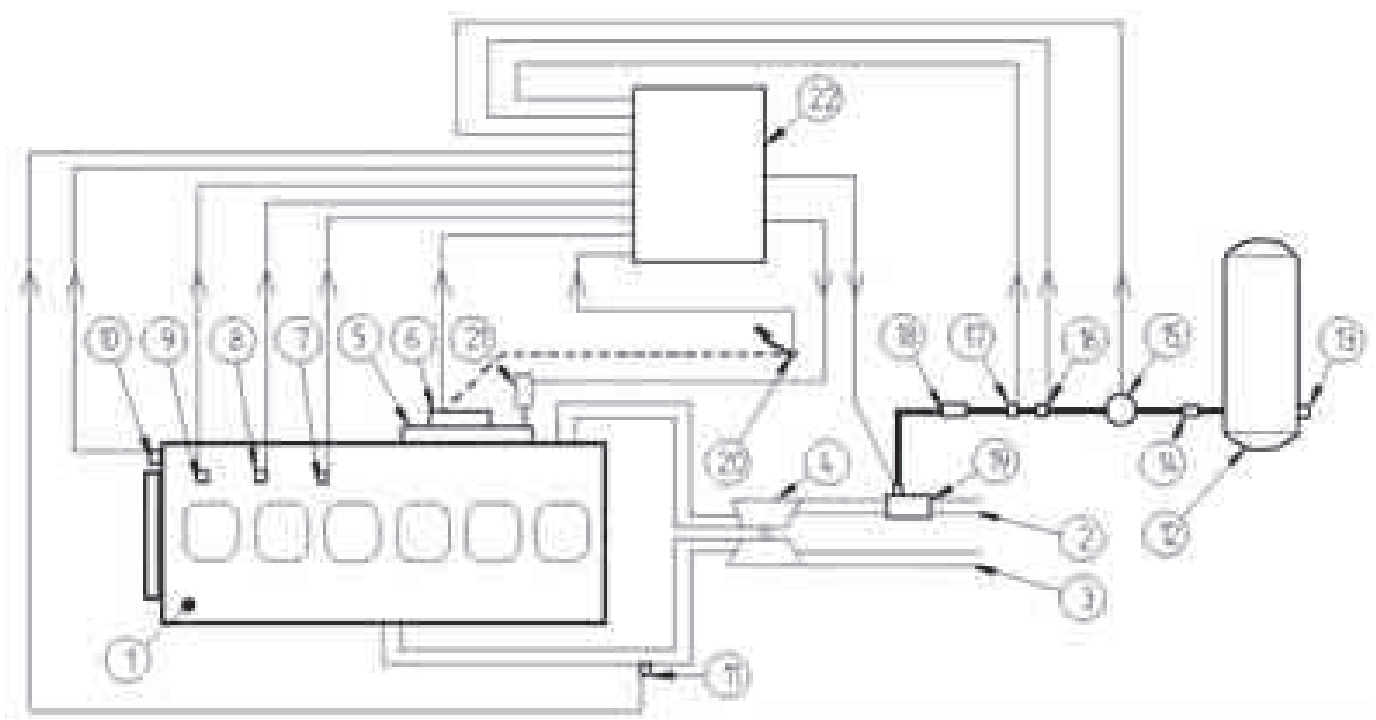

Fig. 10. The biogas installation for CDC 6T-590 engine: 1. CDC 6T-590 engine, 2. air inlet, 3. exhaust pipe, 4. turbocharger, 5. injection pump, 6. mechanical link for reduction of diesel oil dose with the position sensor, 7. knock sensor, 8. manifold pressure sensor, 9. coolant temperature sensor, 10. engine rotation speed sensor, 11. exhaust gases temperature sensor, 12. biogas tank, 13. filling valve, 14.electrovalve, 15. pressure reducing valve, 16. biogas temperature sensor, 17. biogas pressure sensor, 18. biogas filter, 19. biogas injection unit, 20. pedal position sensor, 21. mode of fuelling changing mechanism with actuator, 22. biogas electronic control unit

\section{Conclusions}

The manure biogas can be used as a fuel for dual fuelling of CI engine, which powers the agriculture tractor. The usage of the fuel is limited by the share of methane in the biogas. In addition, the mass share of biogas in the dual fuel mixture should be confined because of the high gaseous fuel consumption and the possible modification of combustion process. The amount of biogas should be limited because of the volume of the storage biogas cylinders. To assure the dual fuel engine operation the biogas cylinders have to be filled daily during the brake of tractor work. The analysis of fuel consumption and the phenomena connected with filling of the engine cylinders as well as the analysis of dual mixture combustion show that it is possible to apply $30 \%$ mass share of biogas in the biodiesel-biogas mixture. For this level of biogas mass share, the changes in combustion process should not significantly affect the engine performance and may contribute to the decreasing of nitric oxides emission because of the lower cylinder temperature.

The usage of biogas as a fuel for agriculture tractor is a practical realization of the idea of sustainable energy production and utilisation of renewable energy sources.

\section{References}

[1] Bocheński, C., Bocheńska, A., Ocena zasobów ropy naftowej i perspektywy jej substytucji biopaliwami, MOTROL, 2008.

[2] Pawlak, G., Możliwości zasilania silnika paliwami wytwarzanymi z odpadów z produkcji żywności, Zeszyty Naukowe Instytutu Pojazdów, 2/2011.

[3] www.globenergia.pl/biomasa/145-wykorzystanie-biogazu-do-produkcji-energii-w-polsce.html

[4] GM Well-to-wheel studie, Ergebnisse Und Schlusse, 2003.

[5] Biomethane from Dairy Waste - A Sourcebook for the Production and Use of Renewable Natural Gas in California, 2005.

[6] AVL BOOST Version 2010, User guide, AVL, 2010.

[7] AVL BOOST Version 2010, Theory, AVL, 2010.

[8] Pawlak, G. The concept of dual fuel highly efficient internal combustion engine, SAE 201001-1480. 